\title{
Studies on synthesis of calcium ferrite-based bio glass ceramics
}

\author{
B R JAGADISH, N PRABHU and D BAHADUR* \\ Department of Melallurgical Enginering and Materials Science, Indian Institule of Technology, Mumbaj 400076, India
}

MS received 9 January 1997

\begin{abstract}
The possibility of synthesizing a Ca-ferrite hased biocompatible glass ceramic has been explored In the following two glass compositions: (i) $28 \mathrm{Na}_{2} \mathrm{O}-8 \mathrm{CaO}-3 \mathrm{P}_{2} \mathrm{O}_{5}-11 \mathrm{Fe}_{2} \mathrm{O}_{3}-50 \mathrm{SiO}_{2}$, and (ii) $25 \mathrm{Na}_{2} \mathrm{O}-8 \mathrm{CaO}-$ $3 \mathrm{P}_{2} \mathrm{O}_{5}-20 \mathrm{Fe}_{2} \mathrm{O}_{3}-41 \mathrm{SiO}_{2}-3 \mathrm{~B}_{2} \mathrm{O}_{3}$ (in weight ratio). The effect of simulated body fluid on the different glasses and glass ceramics was also investigated. While there is no direct evidence for apatite lormation, the weight. Iosses recorded and formation of a Si-rich layer at the surface appears to be an indication of onset of apatite formation. The rate of apatite formation is presumably retarded due to the presence of $\mathrm{AP}^{3+}$ (picked up from $\mathrm{Al}_{2} \mathrm{O}_{3}$ crucible). Ferromagnetic resonance experiments at $9.03 \mathrm{GHz}$ demonstrate that these glass ceramics can possibly be used for microwave hyperthermia.
\end{abstract}

Keywords. J3io glass ceramics; calcium ferrite; hyperthermia; apatite.

\section{Introduction}

It has been shown that bionctive glasses and glass ceramics bond to bone (tissue) by the formation of an apatite layer on the surface (Anderson et al 1990; Hench 1991; Ochura et al 1994). The apatite phase is equivalent chemically and structurally to the mineral phese of the bone and it is this equivalence which is thought to be responsible for the intorfacial bonding (Hench 1991). The formation of surface apatite layer has been investigated by dipping the bioactive glasses and glass ceramics in a simulated body fluid (SBF) (with ion concentrations similar to those in humar blood plasma) or in a Tris buffer solution (TBS) (Anderson et al 1990; Ebisawa et al 1990, 1992a; Kokubo et al 1992; Li et at 1992; Ohtsuki et al 1992).

A promising application of bioactive ferrite-based glass ceramics is in the hyperthermia treatment of cancer. On application of either an atternating magnetic field or microwaves, the bioactive magnetic glass ceramic acts as a localized heating target which leads to selective dissipation of heat to the cancerous tissues. Ebisawa et al (1992b) have successfully demonstrated the use of a bioactive ferimagnetic gylass ceramic (in $\mathrm{Fe}_{2} \mathrm{O}_{3}-\mathrm{SiO}_{2}-$ $\mathrm{CaO}-\mathrm{B}_{2} \mathrm{O}_{3}-\mathrm{P}_{2} \mathrm{O}_{5}$ system) as a thermosed for hyperthermia of cancer using an alternating magnetic field (the soft heating method). Fertomagnetic resonance (FMR) has been used by Nikawa and Okada (1987) for deep heating of the cancerous tissue for microwave hyperthermia. It was found that the energy dissipation rate at the target during FMR was $40 \%$ higher than that of nonresonance

*Author for correspondence microwave heating. Also, the depth of heating increased by nearly $50 \%$ at resonance.

In the present study our objective was to synthesize Ca-ferrite-based ylass ceramics through mucleation and growth $\mathrm{In} \mathrm{CaO}-\mathrm{Na}_{2} \mathrm{O}-\mathrm{P}_{2} \mathrm{O}_{5}-\mathrm{P}_{2} \mathrm{O}_{5}-\mathrm{Fe}_{2} \mathrm{O}_{3}-\mathrm{SiO}_{2}$-based glass. We have futher evaluated the bionctivity of the different glass ceramics in vitro (using a TBS or a SBF solution). The different glass ceramics have been characterized in delail belore and after treating them in SBF/TBS solution. The suitability fot use as thermoseds in microwave hyperthermia has been denonstrated by FMR studies.

\section{Experimental}

Two glasses $\mathrm{G} 1$ and $\mathrm{G} 2$ (compositions given in table 1). were prepared using reagent grade chemicals $\mathrm{Na}_{2} \mathrm{CO}_{3}$, $\mathrm{CaCO}_{3}, \mathrm{CaHPO}_{4} \cdot 2 \mathrm{H}_{2} \mathrm{O}, \mathrm{Fe}_{2} \mathrm{O}_{3}, \mathrm{SiO}_{2}$ and $\mathrm{H}_{3} \mathrm{BO}_{3}$. Melting was done in an alumina crucible and pouring of melts done at $1150^{\circ} \mathrm{C}$ and $1130^{\circ} \mathrm{C}$ respectively. The melt was splat quenched using two steel plates to obtain glass. XRD studies of powder samples were carried out on a Phillips PW480 diffractometer using $\mathrm{CuK}_{u}$ radiation in the scat range $20^{\circ}-100^{\circ}$.

Differential thermal analysis (DTA) was performed on the powder samples using a Dupont model 9900 system, with heating rate of $10^{\circ} \mathrm{C} / \mathrm{min}$ in the temperature range

Table 1. Glass composite in weight percentage.

\begin{tabular}{ccccccc}
\hline & $\mathrm{Na}_{2} \mathrm{O}$ & $\mathrm{CaO}$ & $\mathrm{P}_{2} \mathrm{O}_{5}$ & $\mathrm{Fe}_{2} \mathrm{O}_{3}$ & $\mathrm{SiO}_{2}$ & $\mathrm{~B}_{2} \mathrm{O}_{3}$ \\
\hline $\mathrm{G} 1$ & 28 & 8 & 3 & 11 & 50 & - \\
$\mathrm{G} 2$ & 25 & 8 & 3 & 20 & 41 & 3 \\
\hline
\end{tabular}


$20^{\circ} \mathrm{C}-1000^{\circ} \mathrm{C}$. A typical DTA plot for glass $(\mathrm{G} 1)$ is given in figure 1 . The nucleation and growth temperatures werc estimated from the DTA results and the glasses were accordingly subjected to different heat treatment schedules. The $\mathrm{X}$-lay diffraction technique was used to determine the different phases that formed after heat treatment. Tuble 2 provides a list of various phases formed after different haat treatments.

TBS containing $50 \mathrm{mM}$ Tris (hydroxymethyl) methylamine and $45 \mathrm{mM} \mathrm{HCl}$ was prepared as suggested by Anderson et al (1990) and $\mathrm{Li}$ et al (1992). Samples were dipped in $25 \mathrm{ml}$ of TBS for a period of 30 days. SBF was prepared by dissolving reagent grade chemicals $\mathrm{NaCl}, \mathrm{NaHCO}_{3}, \mathrm{KCl}, \mathrm{MgCl}_{2} \cdot 6 \mathrm{H}_{2} \mathrm{O}_{1} \mathrm{CaCl}_{3} \cdot 2 \mathrm{H}_{2} \mathrm{O}$ and $\mathrm{CaHPO}_{4}-2 \mathrm{H}_{2} \mathrm{O}$ in distilled wares. The solution was buffered by $50 \mathrm{mM}$ Tris (hydroxymethyl) methylamine and $45 \mathrm{nM} \mathrm{HCl}$ (Ebisawa et al 1990. 1992a; Kokubo at al 1992; Ohtsuki et al 1992). Ion concentrations in SBF have been reported by Ohtsuki et al (1992). Samples were dipped in $50 \mathrm{ml}$ of SBF each in stoppered standard flasks. In order to study modifications occurring at the strface, XRD studies weje carried out on samples dipped in TBS and SBF. To study compositional changes occurring at the sulface, energy dispersive X-ray (EDX) analysis was carried out on a few dipped and undipped

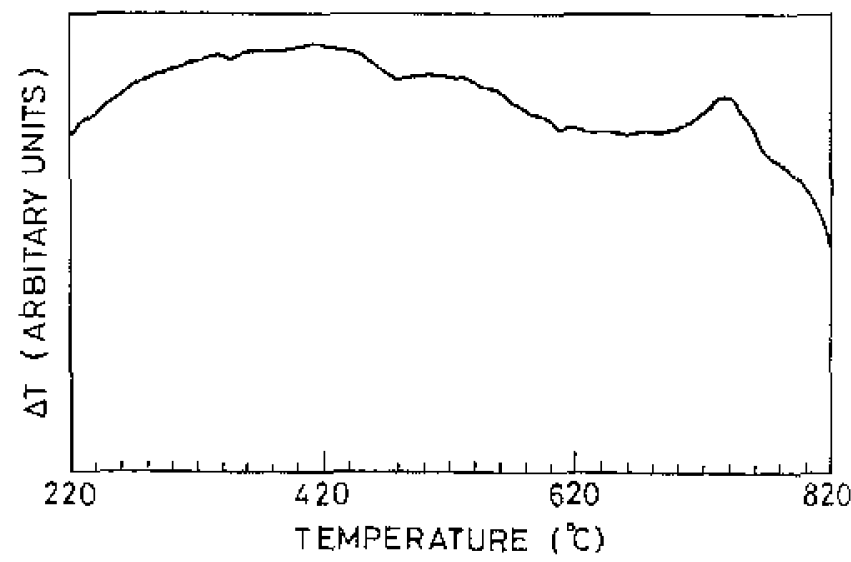

Figure 1. A typieal DTA plot for glass G1. samples. Cambridge Stereoscan 90B system was used for scanning electron microscopy (SEM). Ferromignetic resonance studies of samples were done on a system using microwave frequency $9.07 \mathrm{GHz}$ in scan range $0-4000$ Oe magnetic field.

\section{Results and discussion}

The as-quenched glasses $G 1$ and $G 2$ are amorphous. Figure 2 gives the $X$-tay diffraction patterns of the glass $\mathrm{GI}$ and the glass ceramics $\mathrm{GCl} 1$ and $\mathrm{GCl} 4$. While the

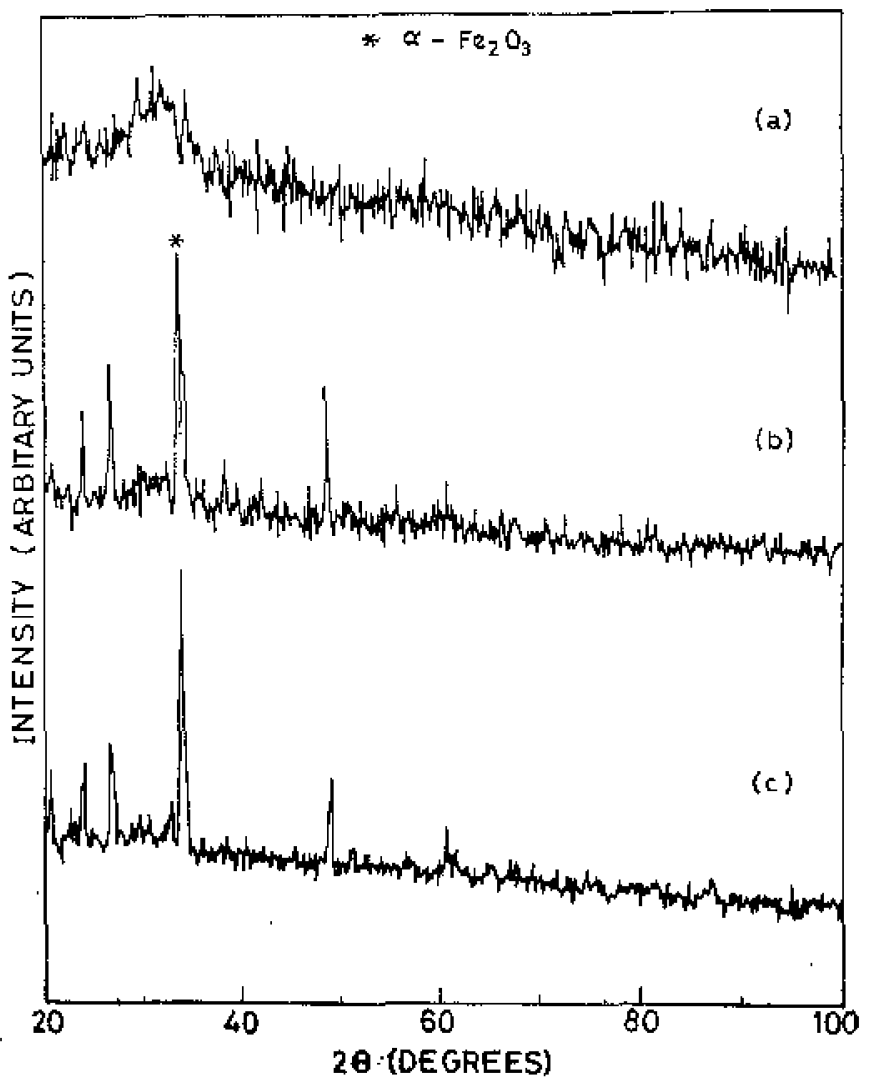

Figure 2. X-ray difliaction patterns of (a) glass $G 1$, (b) GCI and (c) $\mathrm{GCl} 4$.

Table 2. Heat treatment, label and crystalline phases obscrved.

\begin{tabular}{|c|c|c|c|c|}
\hline \multirow[b]{2}{*}{$\begin{array}{l}\text { Glass } \\
\text { ceramic }\end{array}$} & \multirow{2}{*}{$\begin{array}{c}\text { Starting } \\
\text { glass }\end{array}$} & \multicolumn{2}{|c|}{ Heat treatment } & \multirow[b]{2}{*}{$\begin{array}{c}\text { Crystalline phases } \\
\text { presont }\end{array}$} \\
\hline & & Nucleation & Growth & \\
\hline GC1T & G] & $430^{\circ} \mathrm{C} / 1 \mathrm{~h}$ & $780^{\circ} \mathrm{C} / 24 \mathrm{~h}$ & $\mathrm{CaFe}_{4} \mathrm{O}_{7}, \mathrm{anFe}_{2} \mathrm{O}_{3}(\mathrm{MR})$ \\
\hline $\mathrm{GCl} 12$ & $\mathrm{G}:$ & $730^{\circ} \mathrm{C} / 1 \mathrm{~h}$ & $780^{\circ} \mathrm{C} / 24 \mathrm{~h}$ & $\mathrm{CaFe}_{4} \mathrm{O}_{7}, \alpha-\mathrm{Fe}_{2} \mathrm{O}_{3}(\mathrm{MJ})$ \\
\hline $\mathrm{GC} 13$ & Gl & $430^{\circ} \mathrm{C} / 1 \mathrm{~h}$ & $740^{\circ} \mathrm{C} / 24 \mathrm{~h}$ & $\mathrm{CaFe}_{4} \mathrm{O}_{2}$ \\
\hline GC14 & G1 & $430^{\circ} \mathrm{C} / 1 \mathrm{~h}$ & $780^{\circ} \mathrm{C} / 48 \mathrm{~h}$ & $\mathrm{CaFe}_{4} \mathrm{O}_{7}$ \\
\hline $\mathrm{GC} 21$ & 92 & $475^{\circ} \mathrm{C} / 1 \mathrm{~h}$ & $690^{\circ} \mathrm{C} / 24 \mathrm{~h}$ & $\mathrm{CaFe}_{4} \mathrm{O}_{7}, a-\mathrm{Fe}_{2} \mathrm{O}_{3}(\mathrm{MJ})$ \\
\hline $\mathrm{GC} 22$ & $\mathrm{G} 2$ & $570^{\circ} \mathrm{C} / 1 \mathrm{~h}$ & $883^{\mathrm{c}} \mathrm{C} / 24 \mathrm{~h}$ & $\mathrm{CaFe}_{4} \mathrm{O}_{7}, a \mathrm{Fe}_{2} \mathrm{O}_{3}(\mathrm{MR})$ \\
\hline
\end{tabular}

$\mathrm{MJ}=\mathrm{major}, \mathrm{MR}=$ minor. 
sample G1 is completely glassy in nature, the sample GC11 exhibits XRD lines of both $\mathrm{CaFe}_{4} \mathrm{O}_{7}$ and $\alpha-\mathrm{Fe}_{2} \mathrm{O}_{3}$ phase. But, when the growlh time is increased from $24 \mathrm{~h}$ to $48 \mathrm{~h}_{2}$ as in the sumple $\mathrm{GC} 14$, a single $\mathrm{CaFe}_{4} \mathrm{O}_{7}$ ferrite phase is obtained. It is possible that with increase in growth time $a-\mathrm{Fe}_{3} \mathrm{O}$, reacts with $\mathrm{CaO}$ in matrix phase by the following reaction:

$$
\mathrm{CaO}+2 \mathrm{Fe}_{2} \mathrm{O}_{3} \rightarrow \mathrm{CaFc}_{4} \mathrm{O}_{7}
$$

Based on the results shown in table 2 we have observed that when the nucleation temperature is increased from $430^{\circ} \mathrm{C}$ to $730^{\circ} \mathrm{C}$ as in $\mathrm{GCl}$ sample, a higher relative amount of $\alpha-\mathrm{Fe}_{2} \mathrm{O}_{3}$ is obtained. This suggests that $430^{\circ} \mathrm{C}$ is the right nucleation temperature for Ca-ferrite plinse.
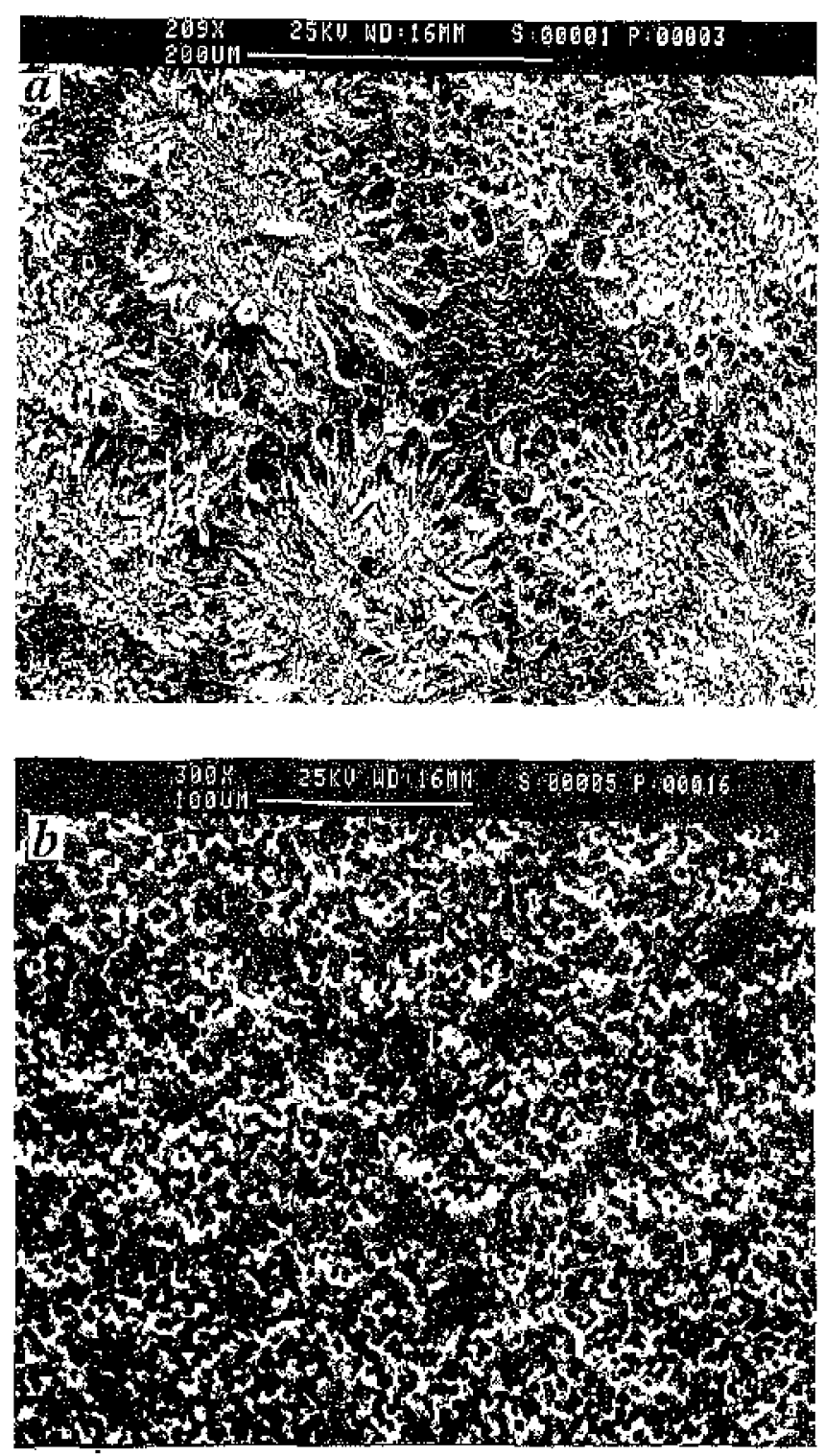

Figure 3. Scanning electron micrographs of glass ceranic samples a. GC12 and b. GC21. while $730^{\circ} \mathrm{C}$ represents the nucleation temperature for $\alpha-\mathrm{Fe}_{2} \mathrm{O}_{3}$ phase. Further, when the growth temperature was decreased to $740^{\circ} \mathrm{C}$ from $780^{\circ} \mathrm{C}$ as in GC13 sample, a single $\mathrm{CaFe}_{4} \mathrm{O}_{7}$ phase was obtained with low glassy background. This indicates that $740^{\circ} \mathrm{C}$ is an optimum growth temperature for $\mathrm{CaFe}_{4} \mathrm{O}_{7}$ phase. The $\mathrm{GC2l}$ and GC22 samples show both the crystalline phases i.e. $\mathrm{CaFe}_{4} \mathrm{O}_{7}$ and $\alpha-\mathrm{Fe}_{2} \mathrm{O}_{3}$. The relative amount of $\alpha-\mathrm{Fe}_{2} \mathrm{O}_{3}$ phase is greater in GC21 than in GC22 sample.

These results from $X$-ray diffraction studies are supported by scanning electron micrographs. It can be seen for sample $\mathrm{GCl} 2$ in figure $3 \mathrm{a}$, that there is at distinct tendency for the second phase to separate as non spherical structure with high connectivity and dendritic growth. There is also a clear evidence for the existerce of two phases in the sample GC21 as seen from figure 3b. The heat treatment process presumably allows enough time for glass in glass phase separation followed by crystallization of $\mathrm{CaFe}_{4} \mathrm{O}_{7}$ and $\alpha-\mathrm{Fe}_{2} \mathrm{O}_{3}$.

Weight losses were recorded alter djpping the glass and glass ceramic samples either in TBS or SBF solution for varying duration. Table 3 gives the weight losses in $\mathrm{mg} / \mathrm{g}$ for the different samples. From this table it car be seen that glass suffers a weight loss of $1-2$ orders of magnitude less than that suffered by the glass ceramics. This is in accordance with the results published in literature which suggest that presence of $\mathrm{Fe}_{2} \mathrm{O}_{3}$ in a glass improves its stability (Ochura et al 1994). On heal treatment, $\mathrm{Fe}_{2} \mathrm{O}_{3}$ presumably enters the crystalline phase, and the residual glassy phase becomes less stable.

For GC11, GC12 and GC13, the weight loss increases with increusing degree of crystallinity (weight loss by $\mathrm{GCl} 3>\mathrm{GCl} 1>\mathrm{GCl} 2$ ). This indicates that greater the extent to which cystalization occurs, the better is the removal of $\mathrm{Fe}_{2} \mathrm{O}_{3}$ from glassy phase and hence more unstable is the glassy phase.

Figure 4 gives the X-ray diffraction patterns of some typical samples GC21, GC21D, GC11D and GC13D. The dipped samples are represented by adding letter $D$ in their label. XRD palterns of samples dipped in TBS/SBF teveal formation of an amorphous surface layer

Table 3. The weight losses for different samples.

\begin{tabular}{|c|c|c|}
\hline \multirow[b]{2}{*}{ Sample } & \multicolumn{2}{|c|}{ Weight loss (mg/g) } \\
\hline & $\begin{array}{c}\text { In TBS alter } \\
30 \text { days }\end{array}$ & $\begin{array}{l}\text { In SBF aller } \\
8 \text { days }\end{array}$ \\
\hline G1 & 0.344 & - \\
\hline $\mathrm{G} 2$ & - & 1.04 \\
\hline $\mathrm{GC} \perp 1$ & $26 \cdot 42$ & - \\
\hline $\mathrm{GCl}$ & 19.84 & 24.86 \\
\hline $\mathrm{GC} 13$ & $30 \cdot 19$ & $12 \cdot 92$ \\
\hline $\mathrm{GC14}$ & $16 \cdot 19$ & - \\
\hline $\operatorname{cc} 21$ & - & $15 \cdot 49$ \\
\hline $\operatorname{Gog} 2$ & - & 25.97 \\
\hline
\end{tabular}




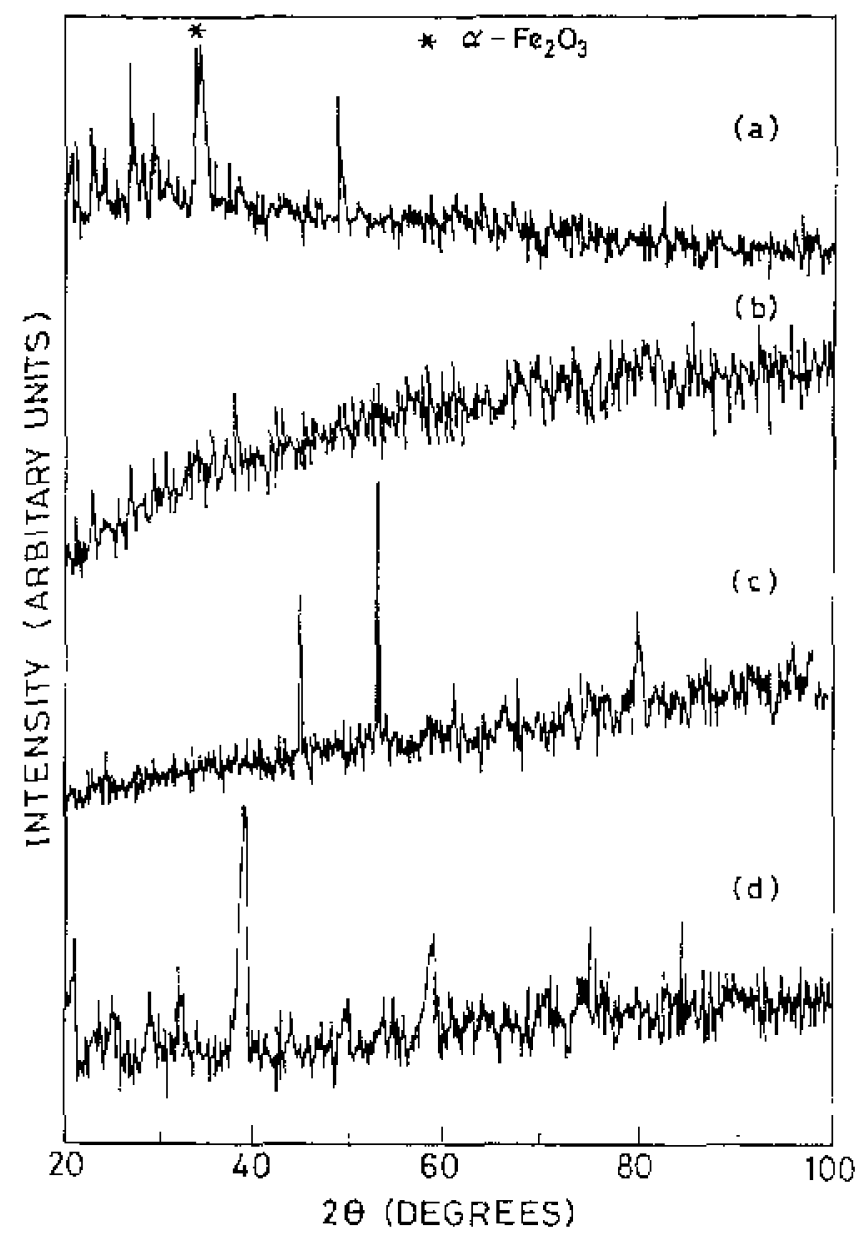

Figure 4. Typical $X$-riby dititaction patterns of samples (a) GC21, (b) GC21D, (c) GCIJD and (d) GC13D. D refers to samples dipped in TBS/SBF. in some cases (i.e. GC12D, GCl4D, GC21D, GC22D). On the other hand, there is formation of a crystalline surface layer as in the sample GCI1D. The sample GCI3D, however remains essentially unmodified except small shift in d values. The crystalline surface layer on GC11D could not be identified.

Modification of the surface is observed only in cases where an appreciable amount of glassy phase is present (as in $\mathrm{GClI}, \mathrm{GCl} 2$ and $\mathrm{GCl} 4$ ). When crystallization has proceeded to a large extent as in GC13, we see no surface modification. This seems to be in agreement with Li et al (1992), who showed that residial glassy phase in a glass ceramic is responsible for the surface

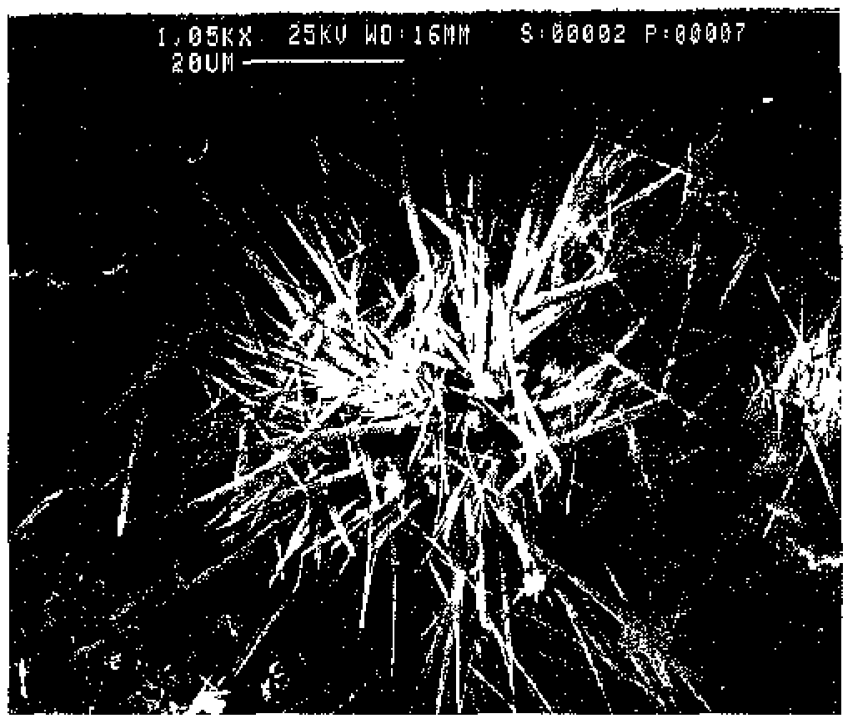

Figure 5. Scannng electron micrugraph of sample GCIID.

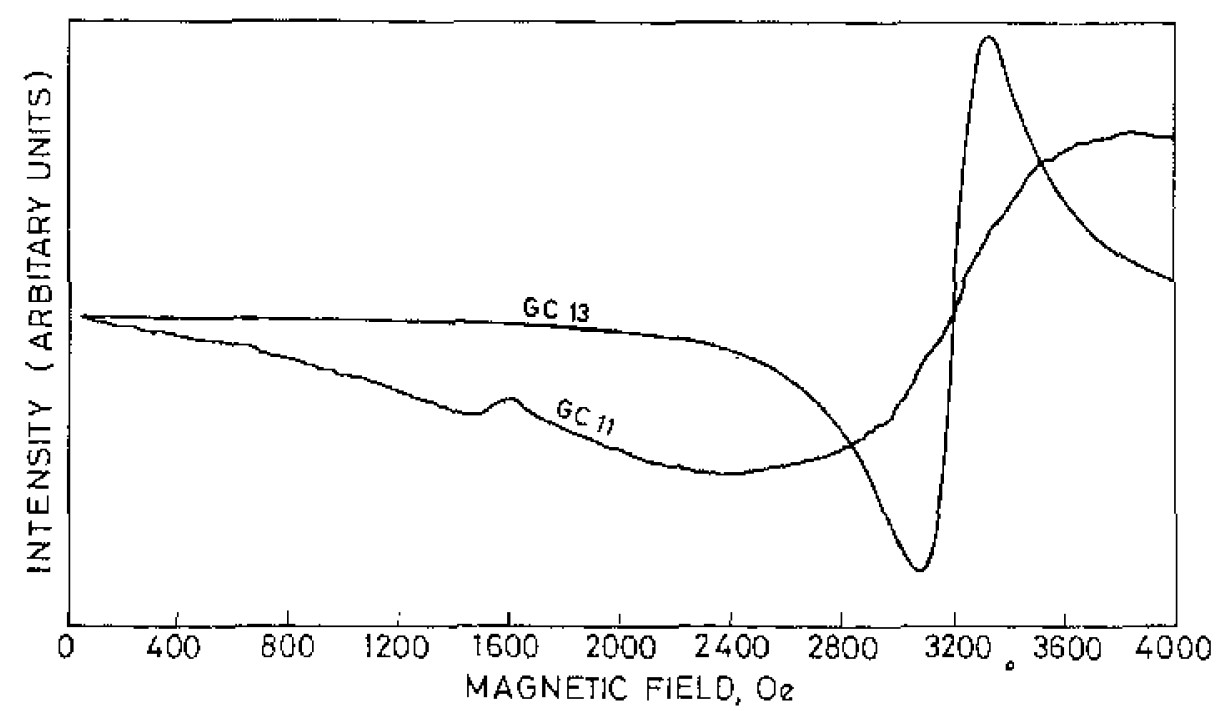

Figure 6. Ferromagnetic resonance spectra lor samples GC13 and GC11. 
modification and an apatite layer formation. Their results show that bioactivity is lost when residual glassy phase is less than 5 wt\%. Glass $G$ ] which showed negligible weight loss, shows no surface modification.

Since we could not jelentify the crystalline phase developed at the surface of GC11D, we attempted to probe the composition of the surface of dipped and undipped samples of GC 11 by LDX. These results indicated that the concentration of sodium on the surface decreases from $22-3 \%$ to $1.43 \%$ on dipping, while the concentration of $\mathrm{Si}$ in the surface increases from $48.5 \%$ to $66.3 \%$ on dipping. According to Hench (1991), Na depletion at the surface along with the formation of a Si-rich layer, is the first step in the formation of an apatite layer on the surface of bioactive glasses and glass ceramics. EDX analysis slows the presence of aluminium picked up flom the alumina crucible. It seems to have occuted during prepuration of the glass. Earlier work (Anderson et al 1990; Kokubo ef al 1992; Ohtsuki et al 1992; Ochuta et al 1994), beve shown that presence of Al retards bionctivity. Anderson et al (1990) suggest that presence of $\mathrm{Al}$ in the silica-rich layer retards the Fomation rate of apatite layer and also stabilizes the glass, thus preventing formation of a $\mathrm{CaO}-\mathrm{P}_{2} \mathrm{O}_{5}$-rich film on top of the Si-rich layer. This could be the reason why only a Si-rich or an amorphous layer is observed in our case without formation of an apatite layer. SEM micrographs of the sample GC1ID show in figure 5 , exhibits fibrous crystals which appen oriented perpendicular to outer surface. Jresumably, the apatite starts nucleating and growing from these silica-rich fibrous grains (Ebisawa et al 1992b).

A ferromagnetic resonance experiment at $9.07 \mathrm{GHz}$ and magnetic fieid up to 40000 e was done on a few samples just to demonstrate absorption of microwave power by the sample. We get broad resonance for GC13 as shown in figure 6 . GCII shows much broader and two resonances at fjelds of 1540 and 31000 . The evidence of absorption of microwave power and the resonance indicates that these glass ceramics can possibly be exploited for microwave hyperthermia using ferromagnetic resonance.

We have explored the formation of bionctive ferritebascd glass ceramics in $\mathrm{Na}_{2} \mathrm{O}-\mathrm{CaO}-\mathrm{P}_{2} \mathrm{O}_{5}-\mathrm{SiO}_{2}-\mathrm{Fe}_{2} \mathrm{O}_{3}-$ based system and examined the possibility of apatite formation on the surfaces of glass ceramics in SBF/TBS solution. Further, absorption of microwave power has been demonstrated through ferromagnetic resonance.

\section{Acknowledgement}

Financial support from CSIR, New Delhi is gratefully acknowledged.

\section{Reforences}

Anderson $O \mathrm{H}$, Lil $\mathrm{G}$, Karlsson $\mathrm{K} \mathrm{H}$, Niemi L N, Mietinen $\mathrm{J}$ and Juhanoja J $1990 \mathrm{~J}$. Mater. Sct: Mater. Med. 1219

Ehisawa $\mathrm{Y}$, Kokubo $\mathrm{T}$, Ohura $\mathrm{K}$ and Yamamuro $\mathrm{T} 1990 \mathrm{~J}$. Mater. Sci.: Mater. Med. 1239

Ebisawa $\mathrm{Y}$, Kokubo $\mathrm{T}$, Ohura $\mathrm{K}$ and Yamamuro $\mathrm{T}$ 1992a $\mathrm{f}$. Mater. Sei.: Maler. Med. 4225

Ebisawa $\mathrm{Y}$ : Murashila $\mathrm{T}$, Kokubo $\mathrm{T}$, Ohum $\mathrm{K}$, lkenga $\mathrm{M}$, Yamamuro T, Kliraoka $M$ and $A b c M$ 1992b Proce of the sixth int, conf. on ferrites (ICFG), Japan (Japan: Society for Powder and Powder Metallurgy) p. 287

Hench L L $1991 \mathrm{~J}$. Am. Ceram. Soc. 741487

Kokubo T, Kishitani $\mathrm{H}$, Ohtsuki $\mathrm{C}$, Sakka $\mathrm{S}$ and Yamenuro $\mathrm{T}$ 1992 J. Mater, Sci.: Mater. Med. 370

Li P, Yang Q, Zlang $\mathrm{F}$ and Kokubo T 1992 J. Mater. Sci.: Mater. Med. 3452

Nikawa $Y$ N and Okada F 1987 IEEE Trans. Magn. 23 2431

Ochura $K$, Nakamura $T$, Yamamuro $T$, Ebisawa $Y$, Kokubo $T$ and Oka M 1994 J. Mater. Sci. Mater, Med. 395

Ohtsuki C, Kokubo T and Yamanuro T 1992 ,I. Mater: Sci.: Mater. Mad. 3119 